Case Report

\title{
Severe Hyperthyroidism Complicated by Agranulocytosis Treated with Therapeutic Plasma Exchange: Case Report and Review of the Literature
}

\author{
Vishnu Garla $\mathbb{D}^{\mathbb{D}}$, Karthik Kovvuru, Shradha Ahuja, Venkatataman Palabindala, \\ Bharat Malhotra $\mathbb{D}$, and Sohail Abdul Salim \\ Department of Internal Medicine, University of Mississippi Medical Center, Jackson, MS, USA \\ Correspondence should be addressed to Vishnu Garla; vishnu.garla@gmail.com
}

Received 1 October 2017; Accepted 17 December 2017; Published 10 January 2018

Academic Editor: Osamu Isozaki

Copyright (c) 2018 Vishnu Garla et al. This is an open access article distributed under the Creative Commons Attribution License, which permits unrestricted use, distribution, and reproduction in any medium, provided the original work is properly cited.

\begin{abstract}
Aim. To present a case of Graves' disease complicated by methimazole induced agranulocytosis treated with therapeutic plasma exchange (TPE) and review of the literature. Case Presentation. A 21-year-old patient with a history of Graves' disease presented to the endocrine clinic. His history was significant for heat intolerance, weight loss, and tremors. Upon examination he had tachycardia, smooth goiter, thyroid bruit, and hyperactive reflexes. He was started on methimazole and metoprolol and thyroidectomy was to be done once his thyroid function tests normalized. On follow-up, the patient symptoms persisted. Complete blood count done showed a white blood cell count of 2100 (4000-11,000 cells/cu mm) with a neutrophil count of $400 \mathrm{cells} / \mathrm{cu} \mathrm{mm}$, consistent with neutropenia. He was admitted to the hospital and underwent 3 cycles of TPE and was also given filgrastim. He improved clinically and his thyroxine (T4) levels also came down. Thyroidectomy was done. He was discharged on levothyroxine for postsurgical hypothyroidism. Conclusion. Plasmapheresis may be useful in the treatment of hyperthyroidism. It works by removing protein bound hormones and also possibly inflammatory cytokines. Further studies are needed to clarify the role of various modalities of TPE in the treatment of hyperthyroidism.
\end{abstract}

\section{Introduction}

Hyperthyroidism is an overproduction and persistent release of thyroid hormones, while thyrotoxicosis refers to the set of clinical manifestations secondary to excessive thyroid hormone action on the tissues [1]. Conventionally thyrotoxicosis is treated medically using agents which inhibit the synthesis and release of thyroid hormones [2]. TPE was first used as a modality in the treatment of hyperthyroidism in the 1970s; however, till this date the role of TPE in the treatment of hyperthyroidism is unclear $[3,4]$.

We present a case of Graves' disease complicated by agranulocytosis treated with TPE along with a pertinent review of the literature.

\section{Case Description}

A 21-year-old male patient presented to the emergency department with neck pain and dysphagia. He had been diagnosed with Graves' disease about 4 years ago; however, he was not taking any medication for the last 2 years. Upon further enquiry, the patient admitted to a history of weight loss, palpitations, tremors, and lack of sleep. Vital signs showed a heart rate of 130/minute, blood pressure of $132 / 67 \mathrm{~mm} \mathrm{Hg}$, respiratory rate of $18 /$ minute, and temperature of 97.8 . Examination revealed an anxious patient with bilateral lid lag, large smooth goiter with a thyroid bruit, and tremors of upper extremities. Laboratory assessment revealed a suppressed $\mathrm{TSH}$, high free $\mathrm{t} 4$, free $\mathrm{t} 3$, positive antithyrotropin receptor antibodies (TRab), and thyroid stimulating immunoglobulin (TSI) confirming the diagnosis of Graves' disease (Table 1). Ultrasound of the neck showed an enlarged hypervascular thyroid gland consistent with Graves' disease. Methimazole and atenolol were started. Thyroidectomy was planned to be done once the thyroid function tests normalized. The patient was discharged from the hospital and was to follow up in the endocrine clinic in 1 month. Upon follow-up in the endocrine clinic, the patient admitted that he had been noncompliant with his medications for a week. He also complained of heat 
TABLE 1: Laboratory assessment on admission.

\begin{tabular}{lc}
\hline TSH $(0.27-4.2 \mathrm{mclu} / \mathrm{ml})$ & $<0.01$ \\
Free t4 $(0.9-1.7 \mathrm{ng} / \mathrm{dl})$ & $>7.77$ \\
Free t3 $(0.8-2.0 \mathrm{ng} / \mathrm{ml})$ & $>6.51$ \\
WBC $(4000-11,000$ cells/cu mm) & 2.1 \\
Absolute neutrophil count & 0.4 \\
TRab $(0-1.75 \mathrm{IU} / \mathrm{L})$ & 26 \\
TSI $(0-1.3)$ & 5.5 \\
\hline
\end{tabular}

intolerance, weight loss, insomnia, palpitations, and a sore throat. Again noted on exam were tachycardia, a smooth goiter with bruit, tremors, and hyperactive reflexes in all extremities. TSH was suppressed, free $\mathrm{t} 4$ and total $\mathrm{t} 3$ were high, and complete blood count showed a low white blood cell count (WBC) and low absolute neutrophil count. A diagnosis of methimazole induced agranulocytosis was made and the patient was admitted to the hospital.

Hematology was consulted for TPE to control hyperthyroidism and also administration of filgrastim for neutropenia. Three treatments of plasma exchanges were done 2 days apart. The replacement fluid used was half albumin and half plasma. Filgrastim was administered daily. WBC and neutrophil counts improved significantly and normalized. Patient continued to improve clinically and his free $\mathrm{t} 4$, previously in the unmeasurable range, did come down. Thyroidectomy was done and pathology revealed an enlarged thyroid with diffuse hyperplasia. Postoperatively, he developed hypocalcemia and was treated with calcium carbonate. Levothyroxine was started for the treatment of postsurgical hypothyroidism. Upon follow-up, a month later in the endocrine clinic, the patient was doing well on levothyroxine.

\section{Methods and Results}

We searched PubMed using the following key words: hyperthyroidism and plasmapheresis. We restricted our search to publications in "English" and involving "human subjects." Abstract of meetings and unpublished results were not included in our study. The last search was done on 6/27/2017.

The initial search resulted in 91 articles; 64 articles were excluded based on the title and abstract. Eligibility criteria were those articles which used TPE to treat hyperthyroidism. 27 articles met the inclusion criteria and were included (Table 2) [4-30].

\section{Discussion}

Thyroxine (T4) has the highest concentration among iodothyronines in the plasma and is produced exclusively by the thyroid; triiodothyronine (T3) is primarily derived (about $80 \%$ ) from the peripheral tissues by deiodination of T4. T4 is about $68 \%$ bound to thyroxine binding globulin (TBG), $11 \%$ to transthyretin, and $20 \%$ to albumin. T3 is $80 \%$ bound to TBG, $9 \%$ to transthyretin, and $11 \%$ to albumin [1]. This extensive protein binding aids in the clearance of thyroid hormones during therapeutic plasma exchange (TPE) [31].

TPE is an extracorporeal blood purification technique used to for eliminating large molecular substances from the plasma [30]. In contrast to dialysis which cannot clear protein bound substances, TPE can clear protein bound substances [13]. The process involves passing the patient's blood through a medical device and separating the plasma out; it is then replaced with a colloid (albumin or plasma) or a combination of crystalloid and colloid. TPE clears thyroid hormones which are protein bound; the colloid used to replace the plasma provides new binding sites for thyroid hormone which are cleared during the next TPE session [6]. Besides thyroid hormones, TPE may help in the clearance of cytokines, deiodinase enzyme, and Graves' antibodies which help not only in the resolution of thyrotoxicosis but also of Graves' ophthalmopathy and pretibial myxedema [31].

There are a number of replacement fluids available, plasma as a replacement fluid offers the advantage of not depleting coagulation factors and also replenishing thyroxine binding globulin [20]. Human albumin offers the advantage of having a larger pool of low affinity binding sites for thyroid hormone [9]. We recommend plasma as the replacement fluid in patients with coagulation disorders or those who are going for surgery.

TPE was first used for the treatment of hyperthyroidism in 1970 by Ashkar et al. on 3 cases of thyroid storm [4]. Our literature review showed that TPE was used in 16 cases not responding to standard treatment, 13 cases of agranulocytosis or other side effects of thionamides, 8 cases of amiodarone induced thyrotoxicosis, and 5 cases for preparation of thyroidectomy. Petry et al. used TPE for the treatment of thyroid storm in postsleeve pneumonectomy patient who did not respond to the conventional treatment and thyroidectomy was considered high risk [22]. Jha et al. reported a case of thyroid storm secondary to excessive consumption thyroid supplements successfully treated with TPE. TPE was particularly useful as the patient had been taking excessive supplements for six days making the use of gastric decontamination and cholestyramine less useful [30].

Lew et al. used double filtration plasmapheresis (DFPP) in a patient with Graves' disease who needed surgical debridement. DFPP is a process where the plasma is first separated from the blood and then large molecules like immunoglobulins and lipoproteins are removed. The advantage would be lesser removal of coagulation factors making it useful in a patient who has to undergo surgery; however, small molecules may not be removed effectively by this procedure [11]. Koball et al. used a single pass albumin dialysis (SPAD) in a patient who had no clinical improvement after two sessions of plasmapheresis. Albumin dialysis has been used to eliminate toxins which accumulate in liver failure. The authors hypothesized that since this was a continuous procedure it would be effective in removing a greater quantity of hormone from the blood. It was also noted that if the plasmapheresis was followed by SPAD it decreased the chance of rebound increase of thyroid hormones [13].

The American society of apheresis categorizes the use of TPE in the treatment of hyperthyroidism as category III 
TABLE 2: Literature review.

\begin{tabular}{|c|c|c|c|c|}
\hline Authors & Cases & Indication & $\begin{array}{l}\text { Indication for } \\
\text { plasmapheresis }\end{array}$ & Outcome \\
\hline Kaderli et al. & 3 & $\begin{array}{l}\text { Amiodarone } \\
\text { induced } \\
\text { thyrotoxicosis }\end{array}$ & $\begin{array}{l}\text { Amiodarone induced } \\
\text { thyrotoxicosis }\end{array}$ & $\begin{array}{l}\text { Underwent } \\
\text { thyroidectomy }\end{array}$ \\
\hline Min et al. & 1 & Graves' disease & $\begin{array}{c}\text { Elevated liver function } \\
\text { tests }\end{array}$ & $\begin{array}{c}\text { Biochemical } \\
\text { improvement with about } \\
40 \% \text { decrease in total T3 }\end{array}$ \\
\hline Aydemir et al. & 1 & Graves' disease & Jaundice & $\begin{array}{c}\text { Biochemical } \\
\text { improvement with } \\
\text { greater than } 60 \% \\
\text { decrease in FT4 and FT3 }\end{array}$ \\
\hline Bilir et al. & 1 & Graves' disease & $\begin{array}{c}\text { Drug induced } \\
\text { angioneurotic edema }\end{array}$ & $\begin{array}{c}\text { Underwent } \\
\text { thyroidectomy }\end{array}$ \\
\hline Carhill et al. & 2 & Graves' disease & $\begin{array}{c}\text { (1) Increase in } \\
\text { transaminases } \\
\text { (2) Unresponsive to } \\
\text { standard treatment }\end{array}$ & $\begin{array}{l}\text { Clinical and biochemical } \\
\text { improvement }\end{array}$ \\
\hline Vyas et al. & 1 & $\begin{array}{l}\text { Exogenous } \\
\text { intoxication }\end{array}$ & Exogenous etiology & $\begin{array}{l}\text { Clinical and biochemical } \\
\text { improvement }\end{array}$ \\
\hline Lew et al. & 1 & Graves' disease & $\begin{array}{l}\text { Agranulocytosis and } \\
\text { hemophagocytosis }\end{array}$ & $\begin{array}{l}\text { Clinical and biochemical } \\
\text { improvement with } \\
\text { greater than } 80 \% \\
\text { decrease in FT4 and FT3 }\end{array}$ \\
\hline Enghofer et al. & 1 & Graves' disease & Fulminant hepatitis & $\begin{array}{c}\text { Underwent } \\
\text { thyroidectomy }\end{array}$ \\
\hline Koball et al. & 1 & Unknown & $\begin{array}{l}\text { Preparation for urgent } \\
\text { thyroidectomy }\end{array}$ & $\begin{array}{c}\text { Clinical and biochemical } \\
\text { improvement }\end{array}$ \\
\hline Ezer et al. & 11 & $\begin{array}{l}\text { (7) Graves' disease } \\
\text { (3) Toxic } \\
\text { multinodular } \\
\text { goiter } \\
\text { (1) Iodine induced } \\
\text { thyrotoxicosis } \\
\end{array}$ & $\begin{array}{l}\text { (7) Unresponsive to } \\
\text { standard treatment } \\
\text { (3) Agranulocytosis } \\
\text { (1) Emergent preparation } \\
\text { for thyroidectomy }\end{array}$ & $\begin{array}{c}\text { Clinical improvement } \\
\text { noted }\end{array}$ \\
\hline Adali et al. & 1 & $\begin{array}{l}\text { Gestational } \\
\text { hyperthyroidism } \\
\text { sec to molar } \\
\text { pregnancy }\end{array}$ & $\begin{array}{l}\text { Emergent preparation } \\
\text { for thyroidectomy }\end{array}$ & $\begin{array}{c}\text { Biochemical } \\
\text { improvement with }>80 \% \\
\text { decrease in FT3 and } \\
>75 \% \text { decrease in FT4 }\end{array}$ \\
\hline Pasimeni et al. & 1 & $\begin{array}{l}\text { Contrast induced } \\
\text { hyperthyroidism }\end{array}$ & $\begin{array}{l}\text { Unresponsive to } \\
\text { methimazole }\end{array}$ & $\begin{array}{c}\text { Clinical and biochemical } \\
\text { improvement }\end{array}$ \\
\hline Azezli et al. & 1 & $\begin{array}{c}\text { Gestational } \\
\text { hyperthyroidism } \\
\text { sec to molar } \\
\text { pregnancy }\end{array}$ & $\begin{array}{c}\text { Preparation for } \\
\text { emergent thyroidectomy }\end{array}$ & $\begin{array}{c}\text { Clinical and biochemical } \\
\text { improvement with } 75.1 \% \\
\text { decrease in free } \mathrm{t} 3 \text { and } \\
63.1 \% \text { decrease in free } 4\end{array}$ \\
\hline Erbil et al. & 1 & $\begin{array}{l}\text { Gestational } \\
\text { hyperthyroidism } \\
\text { sec to molar } \\
\text { pregnancy }\end{array}$ & $\begin{array}{l}\text { Unresponsive to } \\
\text { propylthiouracil }\end{array}$ & $\begin{array}{l}\text { Biochemical } \\
\text { improvement }\end{array}$ \\
\hline Guvenc et al. & 1 & $\begin{array}{c}\text { Toxic multinodular } \\
\text { goiter }\end{array}$ & Agranulocytosis & $\begin{array}{c}\text { Clinical and biochemical } \\
\text { improvement }\end{array}$ \\
\hline Ozbey et al. & 4 & Graves' disease & $\begin{array}{l}\text { (1) Agranulocytosis } \\
\text { (1) PTU induced } \\
\text { vasculitis } \\
\text { (1) Drug induced } \\
\text { urticarial } \\
\text { (1) Hepatotoxicity }\end{array}$ & $\begin{array}{c}\text { Decrease in TT3 by } \\
\text { about } 40-78 \% \text { and FT4 } \\
\text { by }>69 \%\end{array}$ \\
\hline
\end{tabular}


TABLe 2: Continued.

\begin{tabular}{|c|c|c|c|c|}
\hline Authors & Cases & Indication & $\begin{array}{l}\text { Indication for } \\
\text { plasmapheresis }\end{array}$ & Outcome \\
\hline Diamond et al. & 3 & $\begin{array}{l}\text { Amiodarone } \\
\text { induced } \\
\text { thyrotoxicosis }\end{array}$ & $\begin{array}{l}\text { Unresponsive to } \\
\text { standard treatment }\end{array}$ & $\begin{array}{l}\text { Clinical improvement in } \\
2 \text { patients } \\
\text { Mild decrease in the FT4 }\end{array}$ \\
\hline Petry et al. & 1 & Graves' disease & $\begin{array}{l}\text { Status after sleeve } \\
\text { pneumonectomy }\end{array}$ & $\begin{array}{l}\text { Clinical and biochemical } \\
\text { improvement }\end{array}$ \\
\hline Ozdemir et al. & 1 & Hyperthyroidism & $\begin{array}{l}\text { Unresponsive to } \\
\text { standard treatment }\end{array}$ & $\begin{array}{c}\text { Clinical and biochemical } \\
\text { improvement with } 60 \% \\
\text { decrease in FT4 and } 75 \% \\
\text { decrease in FT3 }\end{array}$ \\
\hline Segers et al. & 5 & Thyrotoxicosis & Thyrotoxicosis & $\begin{array}{l}\text { Clinical improvement. } \\
\text { Decrease in FT3 of } \\
63.5 \% \text { and FT4 by } 57.8 \%\end{array}$ \\
\hline Ligtenberg et al. & & $\begin{array}{l}\text { Preparation for } \\
\text { surgery }\end{array}$ & Preparation for surgery & $\begin{array}{l}\text { Decrease in FT3 of 7\% } \\
\text { and } 18 \% \\
\text { Decrease in FT4 of } 0 \% \\
\text { and } 33 \%\end{array}$ \\
\hline Samaras et al. & 1 & $\begin{array}{l}\text { Amiodarone } \\
\text { induced } \\
\text { thyrotoxicosis }\end{array}$ & $\begin{array}{l}\text { Unresponsive to } \\
\text { standard treatment }\end{array}$ & $\begin{array}{c}\text { Failure of treatment } \\
\text { resulting in death of the } \\
\text { patient } \\
\text { Decrease in TT3 and } \\
\text { TT4 noted after TPE } \\
\text { with rebound increase in } \\
\text { levels later }\end{array}$ \\
\hline $\begin{array}{l}\text { Aghini- } \\
\text { Lombardi et } \\
\text { al. }\end{array}$ & 2 & $\begin{array}{l}\text { Amiodarone } \\
\text { induced } \\
\text { thyrotoxicosis }\end{array}$ & Adjunct to methimazole & $\begin{array}{c}\text { Decrease in FT4 and } \\
\text { FT3 } \\
\text { Normalization of TT4 } \\
\text { and TT3 } \\
\end{array}$ \\
\hline De Rosa et al. & 1 & Hyperthyroidism & Agranulocytosis & $\begin{array}{c}\text { Biochemical } \\
\text { improvement with 51\% } \\
\text { decrease in FT3, 47\% } \\
\text { decrease in FT4, 60\% } \\
\text { decrease in TT3, and } \\
53 \% \text { decrease in TT4 }\end{array}$ \\
\hline Binimelis et al. & 6 & $\begin{array}{l}\text { Levothyroxine } \\
\text { intoxication }\end{array}$ & $\begin{array}{c}\text { Cardiac and } \\
\text { neurological symptoms }\end{array}$ & $\begin{array}{l}\text { Clinical and biochemical } \\
\text { improvement in } 15 \text { days }\end{array}$ \\
\hline Jha et al. & 1 & $\begin{array}{l}\text { Medicinal thyroid } \\
\text { overdose }\end{array}$ & $\begin{array}{l}\text { Medicinal thyroid } \\
\text { overdose }\end{array}$ & $\begin{array}{c}\text { Clinical and biochemical } \\
\text { improvement with } 43 \% \\
\text { decrease in TT4 and } \\
68 \% \text { decrease in TT3 }\end{array}$ \\
\hline Ashkar et al. & 3 & Hyperthyroidism & Severe hyperthyroidism & $\begin{array}{c}\text { Clinical improvement in } \\
2-3 \text { days }\end{array}$ \\
\hline
\end{tabular}

Ft4: free thyroxine, Ft3: free triiodothyronine, TT4: total thyroxine, TT3: total triiodothyronine, and TPE: therapeutic plasma exchange.

which states that the role of TPE has not been established in the treatment of thyroid storm. The recommended frequency of treatment is daily to once in three days till clinical improvement is noted [3].

TPE in the treatment of hyperthyroidism can be used when conventional treatment is not working or contraindicated. As noted in our literature review, it can be used in a variety of scenarios with clinical and biochemical improvement. Limitations of TPE include lack of wide spread availability, potential for hemodynamic instability, and the risk of infections.

\section{Conclusions}

In summary, TPE is a useful adjunct in the treatment of hyperthyroidism; its use is suggested in cases with severe thyrotoxicosis with cardiac or neurological complications, or when standard antithyroid treatments are either unresponsive or contraindicated. It is also a useful adjunct in treating cases with levothyroxine overdose. TPE should be done daily till clinical improvement is noted. Thyroid hormone status is monitored by checking free $\mathrm{t} 4$ and free $\mathrm{t} 3$ before and after every TPE session; however, clinical and biochemical dissociation may exist. More research is needed into the usefulness of DFPP and SPAD in the treatment of hyperthyroidism. 


\section{Conflicts of Interest}

The authors declare that there are no conflicts of interest regarding the publication of this paper.

\section{References}

[1] S. Melmed, K. P. onsky, P. Larsen, and H. Kronenberg, Williams Textbook of Endocrinology, S. Mandel and P. Larsen, Eds., Elsevier, 12 edition, 2011.

[2] H. J. Baskin, R. H. Cobin, D. S. Duick et al., "American association of clinical endocrinologists medical guidelines for clinical practice for the evaluation and treatment of hyperthyroidism and hypothyroidism," Endocrine Practice, vol. 8, no. 6, pp. 457469, 2002.

[3] J. Schwartz, A. Padmanabhan, N. Aqui et al., "Guidelines on the use of therapeutic apheresis in clinical practice-evidence-based approach from the writing committee of the american society for apheresis: the seventh special issue," Journal of Clinical Apheresis, vol. 31, no. 3, pp. 149-162, 2016.

[4] F. S. Ashkar, R. B. Katims, W. M. Smoak, and A. J. Gilson, “Thyroid storm treatment with blood exchange and plasmapheresis," Journal of the American Medical Association, vol. 214, no. 7, pp. 1275-1279, 1970.

[5] R. M. Kaderli, R. Fahrner, E. R. Christ et al., "Total thyroidectomy for amiodarone-induced thyrotoxicosis in the hyperthyroid state," Experimental and Clinical Endocrinology \& Diabetes, vol. 124, no. 1, pp. 45-48, 2016.

[6] S. H. Min, A. Phung, T. J. Oh et al., “Therapeutic plasmapheresis enabling radioactive iodine treatment in a patient with thyrotoxicosis," Journal of Korean Medical Science, vol. 30, no. 10, pp. 1531-1534, 2015.

[7] S. Aydemir, Y. Ustundag, T. Bayraktaroglu, I. O. Tekin, I. Peksoy, and A. U. Unal, "Fulminant hepatic failure associated with propylthiouracil: a case report with treatment emphasis on the use of plasmapheresis," Journal of Clinical Apheresis, vol. 20, no. 4, pp. 235-238, 2005.

[8] B. Ekiz Bilir, N. Soysal Atile, O. Kirkizlar et al., "Effectiveness of preoperative plasmapheresis in a pregnancy complicated by hyperthyroidism and anti-thyroid drug-associated angioedema," Gynecological Endocrinology, vol. 29, no. 5, pp. 508-510, 2013.

[9] A. Carhill, A. Gutierrez, R. Lakhia, and R. Nalini, "Surviving the storm: two cases of thyroid storm successfully treated with plasmapheresis," BMJ Case Reports, vol. 2012, 2012.

[10] A. A. Vyas, P. Vyas, N. L. Fillipon, R. Vijayakrishnan, and N. Trivedi, "Successful treatment of thyroid storm with plasmapheresis in a patient with methimazole-induced agranulocytosis.," Endocrine practice : official journal of the American College of Endocrinology and the American Association of Clinical Endocrinologists, vol. 16, no. 4, pp. 673-676, 2010.

[11] W. H. Lew, C.-J. Chang, J.-D. Lin, C.-Y. Cheng, Y.-K. Chen, and T.-I. Lee, "Successful preoperative treatment of a Graves' disease patient with agranulocytosis and hemophagocytosis using double filtration plasmapheresis," Journal of Clinical Apheresis, vol. 26, no. 3, pp. 159-161, 2011.

[12] M. Enghofer, K. Badenhoop, S. Zeuzem et al., "Fulminant hepatitis $\mathrm{A}$ in a patient with severe hyperthyroidism: rapid recovery from hepatic coma after plasmapheresis and total thyroidectomy," The Journal of Clinical Endocrinology \& Metabolism, vol. 85, no. 5, pp. 1765-1769, 2000.
[13] S. Koball, H. Hickstein, M. Gloger et al., "Treatment of thyrotoxic crisis with plasmapheresis and single pass albumin dialysis: a case report: Thoughts and progress," Artificial Organs, vol. 34, no. 2, pp. E55-E58, 2010.

[14] A. Ezer, K. Caliskan, A. Parlakgumus, S. Belli, I. Kozanoglu, and S. Yildirim, "Preoperative therapeutic plasma exchange in patients with thyrotoxicosis," Journal of Clinical Apheresis, vol. 24, no. 3, pp. 111-114, 2009.

[15] E. Adali, R. Yildizhan, A. Kolusari, M. Kurdoglu, and N. Turan, "The use of plasmapheresis for rapid hormonal control in severe hyperthyroidism caused by a partial molar pregnancy," Archives of Gynecology and Obstetrics, vol. 279, no. 4, pp. 569-571, 2009.

[16] G. Pasimeni, F. Caroli, G. Spriano, M. Antonini, R. Baldelli, and M. Appetecchia, "Refractory thyrotoxicosis induced by iodinated contrast agents treated with therapeutic plasma exchange. A case report," Journal of Clinical Apheresis, vol. 23, no. 2, pp. 92-95, 2008.

[17] A. Azezli, T. Bayraktaroglu, S. Topuz, and S. Kalayoglu-Besisik, "Hyperthyroidism in molar pregnancy: rapid preoperative preparation by plasmapheresis and complete improvement after evacuation," Transfusion and Apheresis Science, vol. 36, no. 1, pp. 87-89, 2007.

[18] Y. Erbil, D. Tihan, A. Azezli et al., "Severe hyperthyroidism requiring therapeutic plasmapheresis in a patient with hydatidiform mole," Gynecological Endocrinology, vol. 22, no. 7, pp. 402404, 2006.

[19] B. Guvenc, C. Unsal, E. Gurkan, and S. Dincer, "Plasmapheresis in the treatment of hyperthyroidism associated with agranulocytosis: a case report," Journal of Clinical Apheresis, vol. 19, no. 3, pp. 148-150, 2004.

[20] N. Ozbey, S. Kalayoglu-Besisik, N. Gul, A. Bozbora, E. Sencer, and S. Molvalilar, "Therapeutic plasmapheresis in patients with severe hyperthyroidism in whom antithyroid drugs are contraindicated," International Journal of Clinical Practice, vol. 58, no. 6, pp. 554-558, 2004.

[21] T. H. Diamond, R. Rajagopal, K. Ganda et al., "Plasmapheresis as a potential treatment option for amiodarone-induced thyrotoxicosis [4] (multiple letters)," Internal Medicine Journal, vol. 34, no. 6, pp. 369-371, 2004.

[22] J. Petry, P. E. Y. Van Schil, P. Abrams, and P. G. Jorens, "Plasmapheresis as effective treatment for thyrotoxic storm after sleeve pneumonectomy," The Annals of Thoracic Surgery, vol. 77, no. 5, pp. 1839-1841, 2004.

[23] S. Ozdemir, M. A. Buyukbese, P. Kadioglu, T. Soyasal, H. Senturk, and P. Akin, "Plasmapheresis: an effective therapy for refractory hyperthyroidism in the elderly," Indian Journal of Medical Sciences, vol. 56, no. 2, pp. 65-68, 2002.

[24] O. Segers, H. Spapen, L. Steenssens, R. Cytryn, M. H. Jonckheer, and L. Vanhaelst, "Treatment of severe iodine-induced hyperthyroidism with plasmapheresis.," Acta clinica Belgica, vol. 43, no. 5, pp. 335-343, 1988.

[25] J. Ligtenberg, J. Tulleken, and J. Zijlstra, "Plasmapheresis in thyrotoxicosis [4]," Annals of Internal Medicine, vol. 131, no. 1, pp. 71-72, 1999.

[26] K. Samaras and G. M. Marel, "Failure of plasmapheresis, corticosteroids and thionamides to ameliorate a case of protracted amiodarone-induced thyroiditis," Clinical Endocrinology, vol. 45, no. 3, pp. 365-368, 1996.

[27] F. Aghini-Lombardi, S. Mariotti, P. V. Fosella et al., "Treatment of amiodarone iodine-induced thyrotoxicosis with plasmapheresis and methimazole," Journal of Endocrinological Investigation, vol. 16, no. 10, pp. 823-826, 1993. 
[28] G. De Rosa, A. Testa, G. Menichella et al., "Plasmapheresis in the therapy of hyperthyroidism associated with leukopenia," Haematologica, vol. 76, no. 1, pp. 72-74, 1991.

[29] J. Binimelis, L. Bassas, L. Marruecos et al., "Massive thyroxine intoxication: evaluation of plasma extraction," Intensive Care Medicine, vol. 13, no. 1, pp. 33-38, 1987.

[30] S. Jha, S. Waghdhare, R. Reddi, and P. Bhattacharya, "Thyroid storm due to inappropriate administration of a compounded thyroid hormone preparation successfully treated with plasmapheresis," Thyroid, vol. 22, no. 12, pp. 1283-1286, 2012.

[31] C. Muller, P. Perrin, B. Faller, S. Richter, and F. Chantrel, "Role of plasma exchange in the thyroid storm," Therapeutic Apheresis and Dialysis, vol. 15, no. 6, pp. 522-531, 2011. 


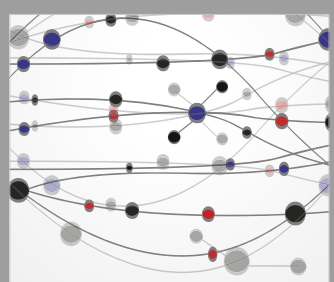

The Scientific World Journal
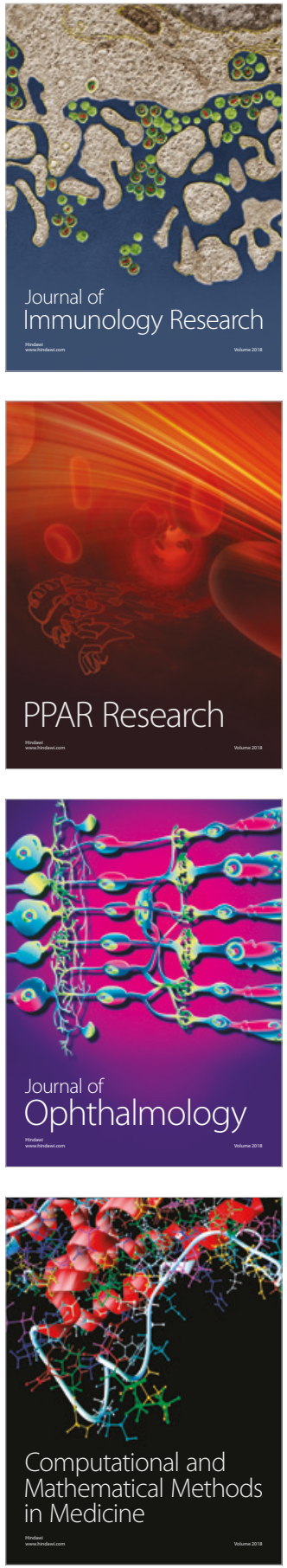

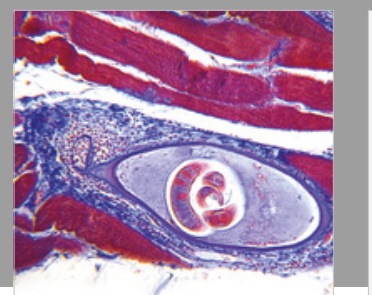

Gastroenterology Research and Practice

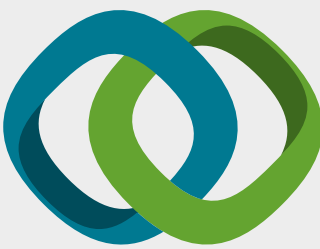

\section{Hindawi}

Submit your manuscripts at

www.hindawi.com
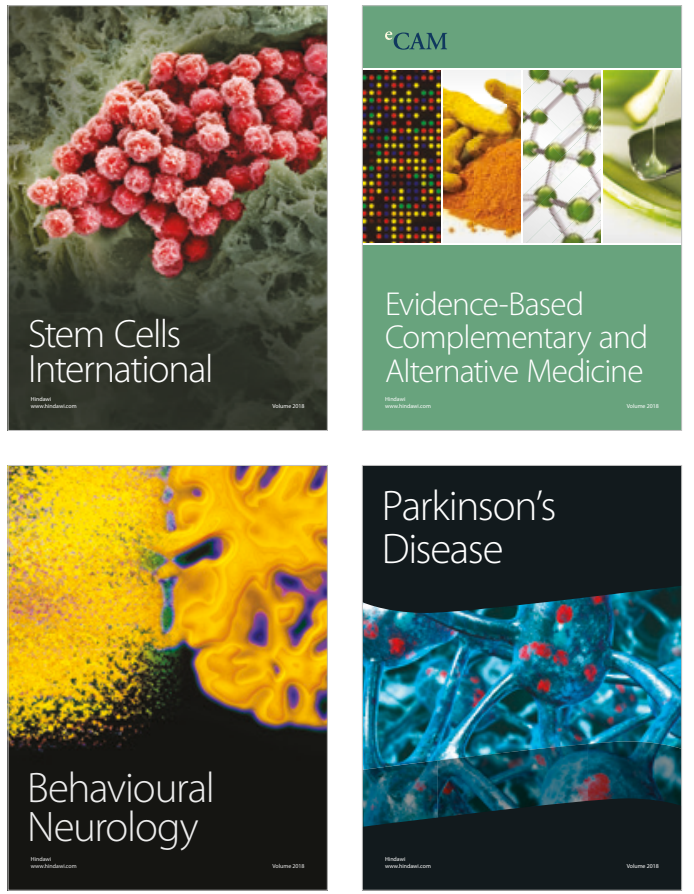

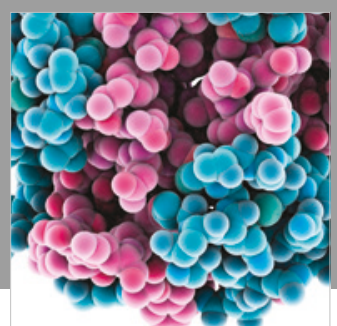

ournal of

Diabetes Research

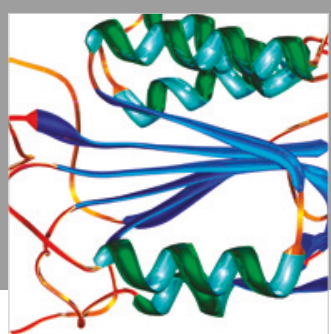

Disease Markers
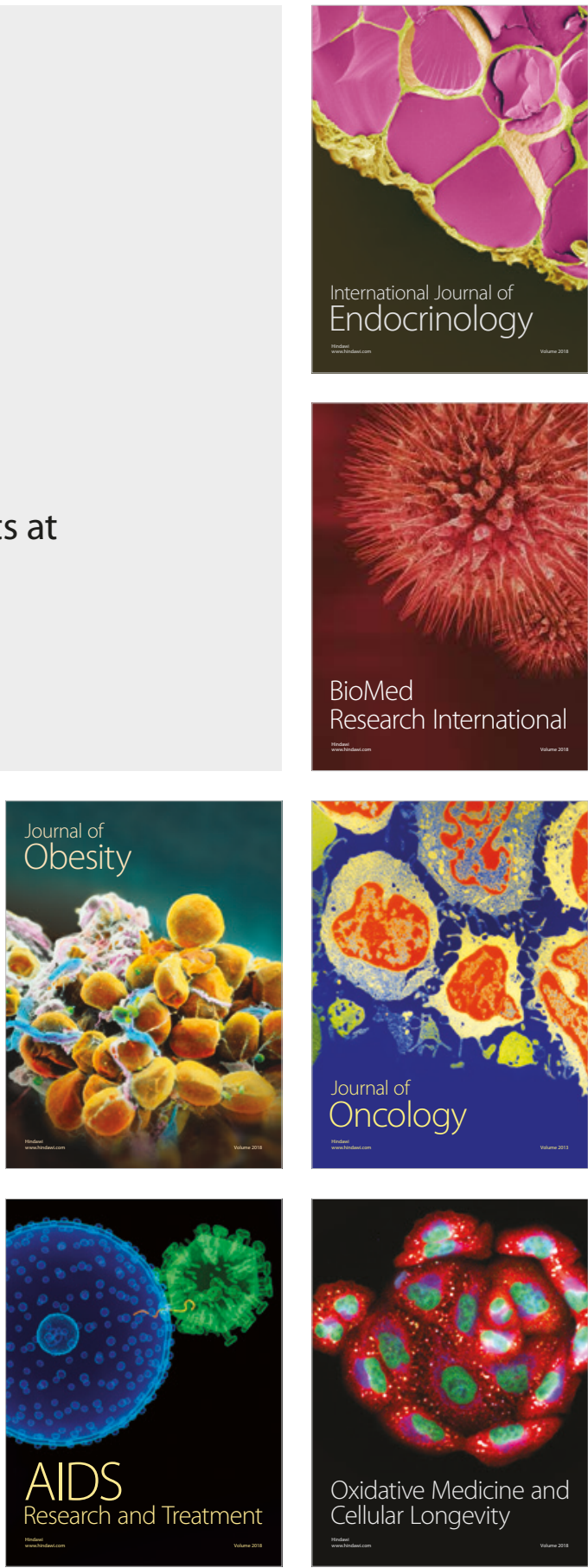